Schütz, I., Freitag, I. \& Wallenstein, R. (1990). Opt. Commun. 77, 221-225.

Shannon, R. D. \& Prewitt, C. T. (1968). Acta Cryst. B25, 925-946.

SHELDRICK, G. M. (1985). SHELXS86. In Crystallographic Computing 3, edited by G. M. Sheldrick, C. KRÜGER \& R. GODDARD, pp. 175-189. Oxford Univ. Press.

Shirong, L., QINGZhen, H., YIfaN, Z., AIDONG, J. \& Chuangtian, C. (1989). Acta Cryst. C45, 1861-1863.

Smith, R. \& Keszler, D. (1989). J. Solid State Chem. 81, 305-313.

Acta Cryst. (1992). C48, 1386-1389
Takahashi, K., Kohda, T., Mryanodai, M., Kanemitsu, Y., Amitan, K. \& Shionoya, S. (1984). J. Lumin. 31/32, 266268.

Thompson, P. D. (1991). PhD Dissertation. Oregan State Univ., USA.

VeLSKo, S. (1988). Private communication. Lawrence Livermore National Laboratory, USA.

Walker, N. \& Stuart, D. (1983). Acta Cryst. A39, 158166.

Yvon, K., Jertschko, W. \& Parthé, E. (1977). J. Appl. Cryst. 10, 73-74.

\title{
Structure of a Te-Methylene-Te Bridged Double-Butterfly Complex
}

\author{
By Kalyan Das and U. C. Sinha \\ Department of Physics, Indian Institute of Technology, Bombay-400 076, India \\ AND PRADeEP Mathur \\ Department of Chemistry, Indian Institute of Technology, Bombay-400 076, India
}

(Received 12 August 1991; accepted 4 December 1991)

\begin{abstract}
T e, T e^{\prime}$-Methylenebis[hexacarbonyl- $\mu$-methyltellurio- $\mu$-tellurio-diiron $(\mathrm{Fe}-\mathrm{Fe})], \quad\left[\mathrm{Fe}_{2}\left(\mu-\mathrm{CH}_{3}-\right.\right.$ $\left.\left.\mathrm{Te})(\mathrm{CO})_{6}\right\}_{2}\left(\mu_{4}-\mathrm{CH}_{2} \mathrm{Te}_{2}\right)\right], M_{r}=1090.01$, monoclinic, $C 2 / c, \quad a=28.865(10), \quad b=13.787(7), \quad c=$ 14.733 (4) $\AA, \beta=104.67(2)^{\circ}, V=5671.86 \AA^{3}, Z=8$, $D_{x}=2.637 \mathrm{Mg} \mathrm{m}^{-3}, \quad \lambda(\mathrm{Mo} K \alpha)=0.7107 \AA, \quad \mu=$ $5.83 \mathrm{~mm}^{-1}, F(000)=4096, T=296 \mathrm{~K}$. Final $R$ and $w R$ are 0.0632 and 0.0598 , respectively, for 2591 observed reflections. The crystal is stacked with two isomers occupying alternative lattice points. Each lattice point is associated with two identical structures with occupation probabilities of 80 and $20 \%$. One $\mathrm{Fe}$ atom $[\mathrm{Fe}(1) / \mathrm{Fe}(3)]$, and a $\mathrm{CO}$ group attached to it, are common in both. For the remaining atoms, a symmetry relationship $1-x, y, \frac{1}{2}-z$ exists between the positions with unequal probabilities. Each molecule contains two butterfly shaped $\left[(\mathrm{CO})_{6} \mathrm{Fe}_{2} \mathrm{Te}\left(\mathrm{CH}_{3}\right) \mathrm{Te}\right]$ units bridged through a $\mathrm{CH}_{2}$ group.
\end{abstract}

Introduction. The dinuclear compound $\mathrm{Fe}_{2}(\mathrm{CO})_{6}(\mu$ $\left.\mathrm{Te}_{2}\right)$ is reported as a favourable starting material for the preparation of various mixed-metal complexes (Day, Lesch \& Rauchfuss, 1982; Mathur, Mavunkal \& Rheingold, 1989). Similarly, the compound $\mathrm{Fe}_{3}(\mathrm{CO})_{9}\left(\mu_{3}-\mathrm{Te}\right)_{2}$ also coordinates with the unsaturated metal fragments but it is relatively more inert towards such addition than the diiron compound. The title compound (I), an unusual product, was obtained from the reaction of $\mathrm{Fe}_{3}(\mathrm{CO})_{9}\left(\mu_{3}-\mathrm{Te}\right)_{2}$ with excess diazomethane (Mathur, Reddy, Das \& Sinha, 0108-2701/92/081386-04\$06.00
1991) at room temperature. Black brick-shaped crystals were obtained from a hexane solution of the compound at $268 \mathrm{~K}$.

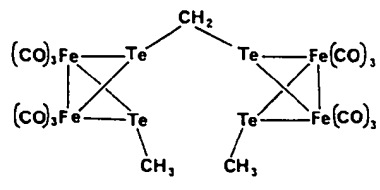

(I)

Experimental. A crystal of dimensions $0.18 \times 0.14 \times$ $0.40 \mathrm{~mm}$ was used for the intensity-data collection on a Nicolet $R 3 \mathrm{~m} / V$ four-circle diffractometer with graphite-monochromated Mo $K \alpha$ radiation. The unit-cell parameters were refined from 20 reflections in the range $6<\theta<13^{\circ}$. A total of 7484 intensities were scanned in the range $2 \leq 2 \theta \leq 45^{\circ}, 0 \leq h \leq 32$, $0 \leq k \leq 15$ and $-16 \leq l \leq 16$, assuming a primitive monoclinic cell. Two reflections $(2,0,10$ and 811$)$, checked every $3600 \mathrm{~s}$, indicated no significant variation in intensities. An empirical correction (North, Phillips \& Mathews, 1968) for absorption and extinction was applied to all data; minimum and maximum transmission factors were 0.298 and 0.371 respectively. Lp corrections were applied. After averaging the equivalent reflections, 3373 unique reflections $\left(R_{\mathrm{int}}=0.076\right)$ were obtained which were used in structure determination. The systematic absences (hkl: $h+k=2 n ; \quad h 0 l: \quad l=2 n+1$ and $h=2 n+1$ ) (c) 1992 International Union of Crystallography 
Table 1. Fractional coordinates $\left(\times 10^{5}\right.$ for $\mathrm{Te}$ and $\mathrm{Fe}$ with s.o.f. 1.00 and 0.8 and $\times 10^{4}$ for the remaining atoms), isotropic temperature factors for $\mathrm{C}$ and $\mathrm{O}$ atoms with s.o.f. 0.2 and equivalent isotropic temperature factors for the remaining atoms

$$
U_{\text {eq }}=(1 / 3) \sum_{i} \sum_{j} U_{i j} a_{i}^{*} a_{j}^{*} \mathbf{a}_{i} \cdot \mathbf{a}_{j} .
$$

\begin{tabular}{|c|c|c|c|c|}
\hline & $x$ & $y$ & $z$ & $U_{\text {eq }} / U_{\text {iso }}$ \\
\hline $\mathrm{Te}(1)$ & $43829(4)$ & $44960(12)$ & $19434(9)$ & $46(2)$ \\
\hline $\mathrm{Te}(2)$ & $33350(4)$ & $53576(6)$ & $19692(10)$ & $49(2)$ \\
\hline $\mathrm{Fe}(1) \dagger$ & $40647(7)$ & 49947 (21) & 33292 (14) & $43(2)$ \\
\hline $\mathrm{Fe}(2)$ & $36441(9)$ & $36312(25)$ & $21825(21)$ & $47(4)$ \\
\hline $\mathrm{Te}(3)$ & 43837 (4) & $-5133(13)$ & $24395(9)$ & $46(2)$ \\
\hline $\mathrm{Te}(4)$ & $33373(4)$ & 3633 (16) & $13609(10)$ & $50(2)$ \\
\hline $\mathrm{Fe}(3) \dagger$ & $40631(7)$ & $112(22)$ & 7357 (14) & $43(2)$ \\
\hline $\mathrm{Fe}(4)$ & $36420(9)$ & $-13630(24)$ & $14412(21)$ & $46(4)$ \\
\hline$C(1)$ & $5000 \ddagger$ & $3591(19)$ & $2500 \ddagger$ & 54 (15) \\
\hline$C(2)$ & $2711(7)$ & $5463(21)$ & $2553(17)$ & 93 (15) \\
\hline$C(3)$ & $5000 \ddagger$ & $8480(23)$ & $2500 \ddagger$ & $54(15)$ \\
\hline$C(4)$ & $2726(8)$ & $10513(22)$ & $160(17)$ & $88(15)$ \\
\hline$C(11) \dagger$ & $3699(5)$ & $4926(16)$ & $4093(10)$ & 64 (13) \\
\hline$O(11) \dagger$ & $3469(4)$ & $4928(16)$ & $4637(9)$ & $117(12)$ \\
\hline$C(12)$ & $4501(7)$ & $4321(16)$ & $4108(14)$ & 54 (14) \\
\hline$O(12)$ & $4814(5)$ & 3871 (13) & $4625(11)$ & 79 (13) \\
\hline$C(13)$ & $4297(7)$ & $6179(17)$ & $3572(15)$ & $71(15)$ \\
\hline$O(13)$ & $4447(7)$ & $6984(14)$ & $3690(13)$ & $105(14)$ \\
\hline$C(21)$ & $3986(7)$ & $2655(14)$ & 2766 (14) & $62(15)$ \\
\hline $\mathrm{O}(21)$ & $4223(6)$ & $1988(12)$ & $3154(12)$ & $93(14)$ \\
\hline$C(22)$ & $3413(8)$ & $3220(18)$ & $1027(15)$ & $76(15)$ \\
\hline $\mathrm{O}(22)$ & $3292(7)$ & 2824 (15) & $281(11)$ & $109(14)$ \\
\hline$C(23)$ & $3166(8)$ & $3326(20)$ & $2638(17)$ & $80(15)$ \\
\hline$O(23)$ & $2845(7)$ & 3075 (19) & 2959 (17) & $157(15)$ \\
\hline$C(31) \dagger$ & $3703(5)$ & $9974(20)$ & $-393(11)$ & $83(14)$ \\
\hline $\mathrm{O}(31) \dagger$ & $3446(6)$ & $9926(18)$ & $-1171(9)$ & 149 (14) \\
\hline$C(32)$ & $4308(7)$ & $11181(17)$ & $756(16)$ & $71(15)$ \\
\hline$O(32)$ & $4454(6)$ & 11983 (14) & $783(14)$ & $101(14)$ \\
\hline$C(33)$ & $4521(7)$ & $9346(17)$ & 415 (13) & $62(14)$ \\
\hline$O(33)$ & $4815(6)$ & 8894 (13) & $162(12)$ & $83(13)$ \\
\hline$C(41)$ & $3993(8)$ & $7633(17)$ & $1232(17)$ & $75(15)$ \\
\hline$O(41)$ & $4225(6)$ & $6987(13)$ & $1024(12)$ & $91(14)$ \\
\hline$C(42)$ & $3410(8)$ & $8154(16)$ & 2338 (15) & $63(15)$ \\
\hline$O(42)$ & $3278(6)$ & 7859 (14) & 2980 (13) & 96 (14) \\
\hline$C(43)$ & $3152(8)$ & $8326(21)$ & 504 (16) & 87 (15) \\
\hline$O(43)$ & $2853(7)$ & $8130(19)$ & $-191(14)$ & $149(15)$ \\
\hline $\mathrm{Te}\left(1^{\prime}\right)$ & $4385(2)$ & 5559 (4) & $1943(4)$ & $34(6)$ \\
\hline $\operatorname{Te}\left(2^{\prime}\right)$ & $3358(2)$ & $4533(5)$ & 2007 (4) & $44(7)$ \\
\hline $\operatorname{Fe}\left(2^{\prime}\right)$ & 3634 (4) & $6331(9)$ & $2245(8)$ & $42(10)$ \\
\hline $\mathrm{Te}\left(3^{\prime}\right)$ & $4383(2)$ & $484(5)$ & $2436(4)$ & $41(6)$ \\
\hline $\mathrm{Te}\left(4^{\prime}\right)$ & $3315(2)$ & 9594 (5) & 1361 (5) & $51(6)$ \\
\hline $\mathrm{Fe}\left(4^{\prime}\right)$ & 3648 (4) & $1395(8)$ & $1524(9)$ & 42 (11) \\
\hline$C\left(1^{\prime}\right)$ & $5000 \ddagger$ & $6434(60)$ & $2500 \pm$ & $13(9)$ \\
\hline$C\left(2^{\prime}\right)$ & $2748(30)$ & $4431(61)$ & $2570(53)$ & $23(9)$ \\
\hline$C\left(3^{\prime}\right)$ & $5000_{+}^{+}$ & $1598(75)$ & $2500 \ddagger$ & $35(10)$ \\
\hline$C\left(4^{\prime}\right)$ & $2683(25)$ & $-463(54)$ & $174(47)$ & $16(9)$ \\
\hline$C\left(12^{\prime}\right)$ & $5460(24)$ & $4350(48)$ & $5932(42)$ & $15(9)$ \\
\hline$O\left(12^{\prime}\right)$ & $5190(19)$ & $3876(39)$ & $5329(36)$ & $21(9)$ \\
\hline$C\left(13^{\prime}\right)$ & 4377 (23) & $3934(42)$ & $3444(45)$ & $13(9)$ \\
\hline$O\left(13^{\prime}\right)$ & $4449(22)$ & $3080(41)$ & $3660(40)$ & $29(9)$ \\
\hline$C\left(21^{\prime}\right)$ & $4024(37)$ & 7334 (67) & 2611 (61) & $35(10)$ \\
\hline$O\left(21^{\prime}\right)$ & $4186(27)$ & $7933(53)$ & $3218(48)$ & $42(9)$ \\
\hline$C\left(22^{\prime}\right)$ & $3440(32)$ & $6812(59)$ & $1128(45)$ & $29(10)$ \\
\hline$O\left(22^{\prime}\right)$ & $3268(23)$ & $7155(47)$ & $352(40)$ & $33(9)$ \\
\hline$C\left(23^{\prime}\right)$ & $3251(26)$ & $6619(61)$ & $2803(53)$ & $27(9)$ \\
\hline$O\left(23^{\prime}\right)$ & $2939(22)$ & $6685(48)$ & $3219(43)$ & $34(9)$ \\
\hline$C\left(32^{\prime}\right)$ & $4203(30)$ & $8842(47)$ & $455(53)$ & $25(9)$ \\
\hline$O\left(32^{\prime}\right)$ & $4404(21)$ & $8061(42)$ & $590(38)$ & $27(9)$ \\
\hline$C\left(33^{\prime}\right)$ & $4469(22)$ & $626(50)$ & $195(48)$ & $17(9)$ \\
\hline$O\left(33^{\prime}\right)$ & $4836(20)$ & $1055(43)$ & $195(38)$ & $25(9)$ \\
\hline$C\left(41^{\prime}\right)$ & $3967(24)$ & $2227(45)$ & $1270(47)$ & $19(9)$ \\
\hline$O\left(41^{\prime}\right)$ & $4243(19)$ & $2903(39)$ & $1314(36)$ & $24(9)$ \\
\hline$C\left(42^{\prime}\right)$ & $3521(29)$ & $1807(58)$ & $2583(50)$ & $26(9)$ \\
\hline$O\left(42^{\prime}\right)$ & $3303(26)$ & $2127(52)$ & 3127 (46) & $41(9)$ \\
\hline$C\left(43^{\prime}\right)$ & $3207(28)$ & $1732(55)$ & $556(49)$ & $19(9)$ \\
\hline$O\left(43^{\prime}\right)$ & $2848(29)$ & 2097 (57) & $119(51)$ & $23(9)$ \\
\hline
\end{tabular}

† Atoms with s.o.f. 1.00. Those atoms labelled with a prime (') have s.o.f. 0.2 ; the s.o.f. for each of the remaining atoms is 0.8 .

$\ddagger$ Coordinate fixed on a twofold axis ( $y$ axis).

indicated the space group to be either $C c$ or $C 2 / c$. Hypercentric distribution of intensities favours the centrosymmetric space group with the existence of
Table 2. Important bond distances $(\AA)$ and bond angles $\left({ }^{\circ}\right)$ with e.s.d.'s in parentheses

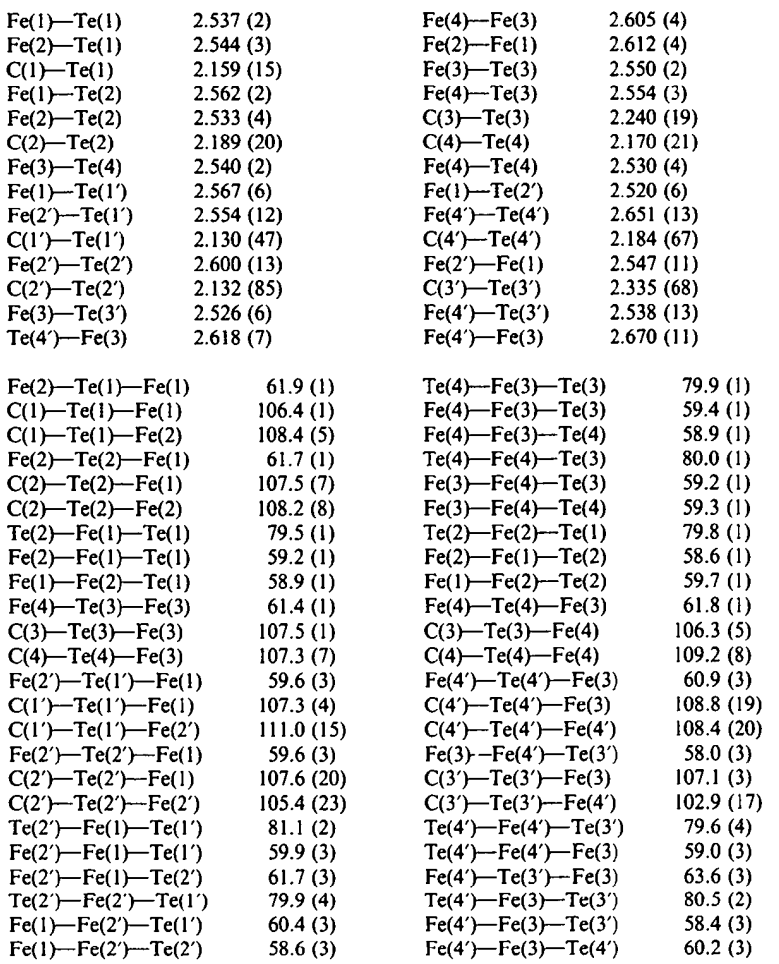

some additional centres of symmetry at general positions. Finally, the space group $C 2 / c$ was confirmed by structure solution.

At first, the structure was solved using MULTAN88 (Debaerdemaeker, Germain, Main, Refaat, Tate \& Woolfson, 1988). While refining the atoms, high Fourier peaks appeared near Te and $\mathrm{Fe}$ atoms (Mathur, Reddy, Das \& Sinha, 1991). Further investigation indicated probable symmetry relationships among the heavy atoms and the nearby peaks.

The structure solution was re-attempted by SIR88 (Burla, Camalli, Cascarano, Giacovazzo, Polidori, Spagna \& Viterbo, 1989) using the detected pseudotranslation symmetry condition $2 h+2 k+3 l=6 n$ (for 1888 refections with $20 \%$ mean fractional scattering power). The triplets were estimated by a Cochran type $P-3$ formula. The phase set with $\mathrm{CFOM}=0.882 \quad[\mathrm{M}(\mathrm{ABS})=1.019 ; \quad \mathrm{ALCOMB}=$ $0.998 ; \quad \mathrm{CPHASE}=1.000 ; \quad \psi$-COMB $=0.583] \quad$ was accepted as the solution. Even in the presence of pseudo-translation symmetry the solution showed excellent FOM (figures of merit) except the $\psi$-FOM. Out of the 12 strongest peaks in the $E$ map, derived from the above phase set, eight peaks were assigned as the positions of $\mathrm{Te}$ and $\mathrm{Fe}$ atoms and each of the remaining four peaks was close to a $\mathrm{Te}$ atom with probable symmetry relation $(x, 1-y, z)$. Conse- 
quently, the crystal was found to be a superposition of two isomers with occupation probabilities 80 and $20 \%$. All the light atoms $(\mathrm{C}$ and $\mathrm{O})$ with site occupany factor (s.o.f.) 0.8 were located from subsequent Fourier maps and those with s.o.f. 0.2 from difference Fourier maps. Later, atoms were refined with isotropic thermal parameters only. SHELX76 (Sheldrick, 1976) was used for structure refinement.

Instead of a complete molecule, two half units [each with type I and type II units] are present in the asymmetric unit; each is bridged to another half unit at $1-x, y, \frac{1}{2}-z$ through a $\mathrm{CH}_{2}$ unit on a crystallographic twofold axis. The $\mathrm{C}$ and $\mathrm{O}$ atoms with $20 \%$ occupancy were refined with isotropic thermal parameters. In the final cycle of least-squares refinement of the structure, 470 independent parameters were refined against 2591 observed reflections, suppressing those with $\left|F_{c}\right|<3.0 \sigma(F)$; (shift/ e.s.d. $)_{\max }=0.252$. Final $R=0.0632$ and $w R=0.0598$ $\left\{\right.$ where $\left.w=1 /\left[\sigma^{2}(F)+0.00016 F^{2}\right]\right\}$. The atomic scattering factors for $\mathrm{Te}$ and $\mathrm{Fe}$ were taken from International Tables for X-ray Crystallography (1974, Vol. IV, pp. 99, 149) and those of other atoms from $S H E L X 76$. In the final difference map, high electrondensity peaks appeared near Te atoms with $(\Delta \rho)_{\max }$ $=1.444$ and $(\Delta \rho)_{\min }=-1.440 \mathrm{e} \AA^{-3} ; \mathrm{H}$ atoms could not be located. A CYBER-180/840 computer was used for all computations.

Discussion. The positional parameters for all non-H atoms are listed in Table $1^{*}$ along with their respective equivalent isotropic or isotropic temperature factors. Important bond lengths and bond angles are given in Table 2. In Fig. 1, $(a)$ and (b) (Motherwell \& Clegg, 1978) represent the molecules (type I) with respective occupation probabilities $80 \%$ (molecule $A$ ) and $20 \%$ (molecule $B$ ), viewed in the same projection. The positions of $\mathrm{Fe}(1) / \mathrm{Fe}(3)$ and a $\mathrm{CO}$ group $[\mathrm{C}(11) / \mathrm{C}(31)$ and $\mathrm{O}(11) / \mathrm{O}(31)]$ attached to it are common in both isomers. As a consequence, each has s.o.f. 1.00. Each molecule consists of two $\mathrm{Fe}_{2} \mathrm{Te}_{2}$ butterfly units in which the $\mathrm{Te}$ atoms are at the 'wing tips'. Two Te atoms in both units are bridged through a $\mathrm{CH}_{2}$ group forming a double-butterfly conformation of the molecule. Each of the two remaining $\mathrm{Te}$ atoms $[\mathrm{Te}(2)]$ are bonded to a methyl group. The methyl groups attached to the outer Te atoms $[\mathrm{Te}(2), \mathrm{Te}(4)]$ are at similar $\mathrm{Te}-\mathrm{C}$ distances with an average of $2.184(20) \AA$. In contrast, the $\mathrm{C}-\mathrm{Te}$ bond lengths associated with the bridging

\footnotetext{
* Lists of structure factors, anisotropic thermal parameters and bond distances and angles have been deposited with the British Library Document Supply Centre as Supplementary Publication No. SUP 54938 (22 pp.). Copies may be obtained through The Technical Editor, International Union of Crystallography, 5 Abbey Square, Chester $\mathrm{CH} 1$ 2HU, England. [CIF reference: AL0505]
}

methyls $[C(1)$ and $C(3)]$ are significantly different from each other: $\mathrm{C}(1)-\mathrm{Te}(1) 2.159$ (15) and $\mathrm{C}(3)-$ $\mathrm{Te}(3) 2.240$ (19) $\AA$. The $\mathrm{Fe}-\mathrm{Fe}$ bond, the bridging Te atoms and the three terminally bonded carbonyl groups form a distorted octahedral conformation around each $\mathrm{Fe}$ atom. As a consequence, $\mathrm{Fe}-\mathrm{Fe}-\mathrm{Te}$ and $\mathrm{Fe}-\mathrm{Te}-\mathrm{Fe}$ angles are about $60^{\circ}$ with maximum deviation $3.6^{\circ}$. In the butterfly cores, the average $\mathrm{Te}-\mathrm{Fe}$ distance is 2.544 (3)/2.579 (9) $\AA$ and the average $\mathrm{Fe}-\mathrm{Fe}$ distance is $2.608(4) /$ 2.608 (13) $\AA$ for molecule $A$ /molecule $B$. The average Te $\cdots$ Te non-bonding distance, $3.524(5) \AA$, is larger than that observed in $(\mathrm{CO})_{9} \mathrm{Fe}_{3}\left(\mu-\mathrm{TeCH}_{2} \mathrm{Te}\right)$ (Mathur, Reddy \& Bohra, 1991) resulting in a greater opening of the $\mathrm{Fe}_{2} \mathrm{Te}_{2}$ butterflies. This is also reflected in the higher $\mathrm{Te}-\mathrm{Fe}-\mathrm{Te}$ bond angles, average $79.98(2)^{\circ}$ compared to $75^{\circ}$ in $(\mathrm{CO})_{6} \mathrm{Fe}_{2}(\mu$ $\mathrm{TeCH}_{2} \mathrm{Te}$ ) (Day, Lesch \& Rauchfuss, 1982). The arrangement of the molecules (with s.o.f. 0.8) along the $b$ axis (range $-b / 2$ to $b / 2$ ) in Fig. 2 shows the

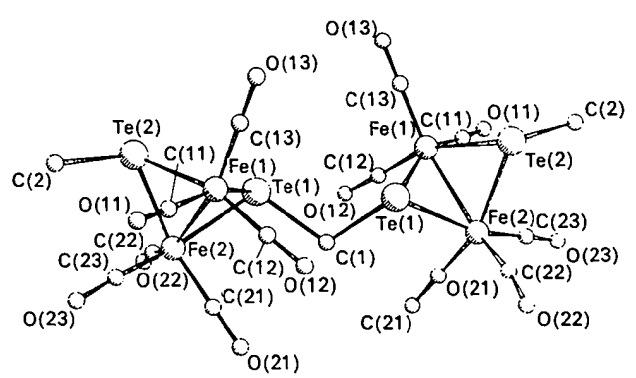

(a)

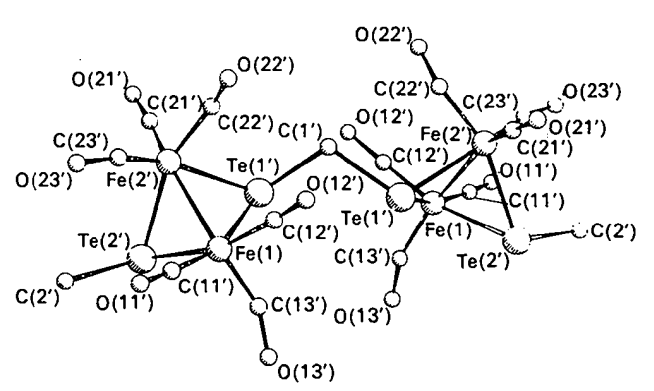

(b)

Fig. 1. Perspective view of the molecule with (a) $80 \%$ occupancy and (b) $20 \%$ occupancy.

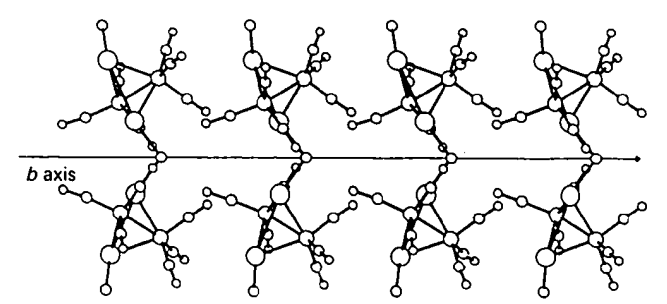

Fig. 2. Stacking of the molecules (occupancy $80 \%$ ) along the $b$ axis. 
presence of additional centres of symmetry apart from the space group symmetries. No short intermolecular distances were observed.

We are grateful to Professor A. Chakravorty for extending the National Single Crystal Diffractometer Facility at the Indian Association of Cultivation of Science, Calcutta, and Dr D. Ray and Mr P. Basu for assistance with the data collection. KD is thankful to Professor C. Giacovazzo for providing the copy of SIR88 and for vital suggestions.

\section{References}

Burla, M. C., Camalli, M., Cascarano, G., Giacovazzo, C., Polidori, G., Spagna, R. \& Viterbo, D. (1989). J. Appl. Cryst. 22, 389-393.
Day, V. W., Lesch, D. A. \& Rauchfuss, T. B. (1982). J. Am. Chem. Soc. 104, 1290-1295.

Debaerdemaeker, T., Germain, G., Main, P., Refaat, L. S., TATE, C. \& WoOlfson, M. M. (1988). MULTAN88. A System of Computer Programs for the Automatic Solution of Crystal Structures from X-ray Diffraction Data. Univs. of York, England, and Louvain, Belgium.

Mathur, P., Mavunkal, I. J. \& Rheingold, A. L. (1989). J. Chem. Soc. Chem. Commun. pp. 382-384.

Mathur, P., RedDy, V. D. \& BohrA, R. (1991). J. Organomet. Chem. 401, 339-346.

Mathur, P., Reddy, V. D., Das, K. \& Sinha, U. C. (1991). J. Organomet. Chem. 409, 255-261.

Motherwell, W. D. S. \& ClegG, W. (1978). PLUTO. Program for plotting molecular and crystal structures. Univ. of Cambridge, England.

North, A. C. T., Phillips, D. C. \& Mathews, F. S. (1968). Acta Cryst. A24, 351-359.

SHELDRICK, G. M. (1976). SHELX76. Program for crystal structure determination. Univ. of Cambridge, England.

Acta Cryst. (1992). C48, 1389-1394

\title{
Structures of Partially Deuterated Sodium Hydrogen Succinate at 295 and $120 \mathrm{~K}$ and Rubidium Hydrogen Succinate at $120 \mathrm{~K}$
}

\author{
BY NiCOLINE KALSBEEK \\ Department of Chemistry, The H.C. Orsted Institute, University of Copenhagen, Universitetsparken 5, \\ DK-2100 Copenhagen Ø, Denmark
}

(Received 30 October 1991; accepted 17 December 1991)

Abstract. $\mathrm{Na}^{+} . \mathrm{C}_{4}(\mathrm{H}, \mathrm{D}) \mathrm{H}_{4} \mathrm{O}_{4}^{-}, \quad M_{r}=140.07$ (undeuterated), monoclinic, $C 2 / c, Z=4, F(000)=288$; at $\quad T=295 \mathrm{~K}: a=9.217(1), \quad b=9.998(1), \quad c=$ 7.365 (1) $\AA, \beta=117.07(1)^{\circ}, V=604.3(3) \AA^{3}, D_{x}=$ $1.539 \mathrm{~g} \mathrm{~cm}^{-3}, \quad \lambda(\mathrm{Cu} K \bar{\alpha})=1.54184 \AA, \quad \mu=$ $17.667 \mathrm{~cm}^{-1}, R=0.036$ for 572 observed reflections; at $T=120 \mathrm{~K}: \quad a=8.844(2), \quad b=10.284(3), \quad c=$ $7.349(2) \AA, \beta=117.33(2)^{\circ}, V=593.8(6) \AA^{3}, D_{x}=$ $1.567 \mathrm{~g} \mathrm{~cm}^{-3}, \quad \lambda($ Mo $K \bar{\alpha})=0.71073 \AA, \quad \mu=$ $1.886 \mathrm{~cm}^{-1}, R=0.028$ for 1891 observed reflections. $\mathrm{Rb}^{+} . \mathrm{C}_{4} \mathrm{H}_{5} \mathrm{O}_{4}^{-}, M_{r}=202.55$, monoclinic, $C 2 / c, a=$ 16.927 (3) $, \quad b=6.1050(6), \quad c=6.3343$ (9) $\AA, \quad \beta=$ $109.17(1)^{\circ}, \quad V=618.3(3) \AA^{3}, \quad Z=4, \quad D_{x}=$ $2.176 \mathrm{~g} \mathrm{~cm}^{-3}, \quad \lambda($ Mo $K \bar{\alpha})=0.71073 \AA, \quad \mu=$ $77.299 \mathrm{~cm}^{-1}, F(000)=392, T=120 \mathrm{~K}, R=0.031$ for 1692 observed reflections. No significant discrepancies are observed in the crystal structure of partially deuterated sodium hydrogen succinate at 295 and $120 \mathrm{~K}$. In this salt the hydrogen succinate ions are linked by short crystallographically symmetric hydrogen bonds across an inversion centre and in rubidium hydrogen succinate across a twofold axis forming infinite chains in the structure. The length of the short hydrogen bond is 2.4272 (9) $\AA$ at $295 \mathrm{~K}$

$0108-2701 / 92 / 081389-06 \$ 06.00$ and $2.4295(5) \AA$ at $120 \mathrm{~K}$ in partially deuterated sodium hydrogen succinate and $2.4406(15) \AA$ in rubidium hydrogen succinate. In both salts the $H$ atom in the short hydrogen bond is best described by two equally populated sites on each side of the centre of the hydrogen bond. The $\mathrm{Na}^{+}$ion is coordinated by six $O$ atoms with four short $(2.37-2.40 \AA)$ and two long $(2.58 \AA) \mathrm{Na}-\mathrm{O}$ distances forming an irregular octahedron. The coordination polyhedron for the $\mathrm{Rb}^{+}$ion is a square antiprism formed by eight $\mathrm{O}$ atoms with $\mathrm{Rb}-\mathrm{O}$ distances in the range 2.92-3.02 $\AA$.

Introduction. The crystal structure determinations of partially deuterated sodium hydrogen succinate (1) and rubidium hydrogen succinate (2) were performed as a continuation of earlier studies of acid salts of malonic acid and succinic acid with special interest in the hydrogen bonding (Kalsbeek \& Larsen, 1991; Kalsbeek, 1991, 1992). Acid salts of carboxylic acids and dicarboxylic acids have been extensively investigated, both structurally (Speakman, 1972) and spectroscopically (Hadži, 1965).

(C) 1992 International Union of Crystallography 